\section{The Effect of Profitability, Leverage and Company Size on Tax Avoidance in the Automotive Sector Manufacturing Companies}

\author{
Amelia Oktrivina Siregar \\ Economics and Business Facukty, Universitas Pancasilas Jakarta
}

\begin{abstract}
The purpose of this research is to examine the effect of profitability, leverage and company size on tax avoidance in the automotive sector manufacturing companies in the 2012-2019 period. The sample in this study consisted of four companies that entered consistently during the research year. The period used in this research is eight years, from 2012 until 2019. The analysis data technique is panel data regression. The method used is purposive sampling method. The results of this research indicate that partially the profitability variable has a negative effect on tax avoidance. Leverage has a positive effect on tax avoidance. Company size has no effect on tax avoidance. While simultaneous testing shows that the variable profitability, leverage and company size affect tax avoidance.
\end{abstract}

\section{Keywords:}

Profitability, Leverage, Company Size, Tax Avoidance

Corresponding Author:

Amelia Oktrivina Siregar

Fakultas Ekonomi dan Bisnis, Universitas Pancasilas Jakarta

Email: ameliaoktrivina@univpancasila.ac.id

DOI: https://doi.org/10.36407/akurasi.v3i2.522
AKURASI
Received: 12 Aug 2021

Accepted: 25 Aug 2021

Online: 31 Aug 2021

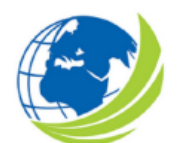

Akurasi: Jurnal Riset Akuntansi dan Keuangan, Vol 3, No.2, 2021, pp. $103-118$ eISSN 2685-2888

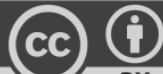

(C) The Author(s) 2021

CC BYThis license allows reusers to distribute, remix, adapt, and build upon the material in any medium or format, so long as attribution is given to the creator. The license allows for commercial use. 


\section{INTRODUCTION}

Tax is a mandatory contribution to the state owed by an individual or entity that is coercive under the law and does not give direct compensation. This definition was written in Law no. 6 of 1983 which was last amended by Law no. 16 of 2009 concerning General Provisions and Tax Procedures (UU KUP). This provides an understanding that taxes have a coercive nature, which means they put a particular burden on the insurer. The accounting side also explains that taxes are costs / expenses that will reduce net income, which is contrary to the goal of all business entities that want to have large profits. These factors make taxes a burden and an obligation, which can trigger tax avoidance (Wibawa et a;., 2016).

Tax avoidance in the tax management literature is generally considered a legal tax management effort because it makes more use of "loopholes" in the applicable tax regulations. According to Wijaya (2016), even until now, the method of tax avoidance itself is not something that violates tax regulations, because it is done by taking advantage of tax loopholes in order to reduce or minimize tax obligations without violating tax law. Tax avoidance done by companies, usually through policies taken by company leaders as decision makers, is not something accidental.

In recent years, there have been many cases of tax evasion. In Indonesia, several companies were involved in cases related to tax evasion, one of which happened in 2014, which was a tax evasion case carried out by PT. Astra International, Tbk (ASII) with one of its subsidiaries, PT. Toyota Motor Manufacturing Indonesia (TMMIN), that was found to use transactions between affiliated companies at home and abroad (transfer pricing) to avoid paying taxes. The mode used is to transfer the burden of excess profits from one country to another that applies a lower tax rate (tax haven). The transfer of expenses is done by manipulating prices unreasonably.

In 2016, the Directorate General of Taxes of the Ministry of Finance (DGT of the Ministry of Finance) stated that as many as 2000 multinational companies operating in Indonesia did not pay Income Tax (PPh), specifically the Corporate Income Tax 25 and 29. These foreign companies did not pay their taxes for up to 10 years. This tax avoidance practice is carried out by means of transfer pricing or diverting taxable profits or net incomes from Indonesia to other countries. There is also a profit reduction method that occurs due to royalty payments and unreasonable purchases of raw materials, as well as the company's reason for allegedly avoiding taxes due to continuous losses.

The impact of the implementation of tax planning, both on company performance and stock performance in the capital market and on stakeholders, has been widely studied and researched. Tax research related to company management compliance with corporate income tax payments is one of the serious problems within companies. The profit generated by the company is a measure of management success in managing a company. The company's earnings are reported through earnings management in accordance with the objectives and motivations that underlie the report. In calculating the amount of tax that must be paid to the Government, there is a dualism in the basis of calculating tax differences, which are the taxes according to the tax authorities and according to company calculations. Based on the phenomena explained above, there are several factors that can affect Tax Avoidance, which include: profitability, leverage and company size.

Mahaputra (2016) in his research showed that ROA had a positive effect on tax avoidance. A positive ROA is needed by the company to provide profits as a company's operating activities. A good company's performance is indicated by the high value of ROA expressed in percentages, and the high profitability of the company is indicated by their generated net profit. Companies that earn profits would usually be assumed to do tax avoidance because the company is able to manage its income and tax payments. A negative ROA is caused by the company income being in a negative (loss) condition as well. This shows that the invested capital as a whole has not been able to generate profits. When a company is in a state of loss, they have no obligation to pay taxes so there is no need to do tax evasion.

The policies taken by the company have a significant role in the level of corporate tax avoidance, such as in determining the company's financing in the form of debt or leverage. According to Kurniasih and Sari (2013) leverage is an increase in the amount of debt which results 
in the addition of new cost items in the form of interest and a reduction in the income tax cost of corporate taxpayers. In measuring and calculating the performance of the company's liabilities and equity, it is necessary to make measurements using the Debt to Equity Ratio. In this case, the Debt to Equity Ratio is a financial ratio used by the company in making decisions to show the financing of a company from the source of debt, which reflects a higher value of the company. The relationship between the Debt to Equity Ratio (DER) and Tax Avoidance is such that if the DER is high, the debt is high, if the debt is high, the interest is also high, if the interest is high, it would have to reduce profits and reduce taxes. According to previous research conducted by Yoannis at al (2017), leverage has a positive effect on tax avoidance and Leverage (DER) could be defined as financial funding by companies originating from the use of debt which can provide benefits in the form of reduction in tax burden because the use of debt can cause interest expenses which reduce the income subjected to corporate tax. According to previous research conducted by Wastam I.G.A.M et al (2017) leverage has a negative effect on ax Avoidance.

The larger the size of a company, the more complex the transactions they carry out regularly, which will allow the company to take advantage of existing loopholes and commit tax avoidance actions from each transaction. Tax avoidance has elements of confidentiality that reduce the transparency of a company, therefore it is very necessary to establish good corporate governance. From the description above, the research problem can be formulated as how the influence of profitability, leverage and company size affect tax avoidance. For this reason, researchers are interested in conducting an empirical test the effect of profitability, leverage, company size and institutional ownership with moderation of gender diversification of directors on tax avoidance in manufacturing companies in the automotive sector.

According to Mamduh M. Hanafi (2016: 313), the trade-off theory has the implication that managers will think in terms of trade-offs between tax savings and bankruptcy costs in determining capital structure. Losses on the use of debt can be caused by bankruptcy costs and agency costs. The Trade Off model cannot be used to accurately determine the optimal model of a company. However, through this model, a conclusion can be drawn about the use of debt where it can lead to a decrease in the tax cost as a part of cost burden, which then results in reduced company profits so that it is less likely for companies to do tax avoidance.

\section{LITERATURE REVIEW}

In the agency theory proposed by Jensen and Meckling (1976), agency relationships arise when one or more people (principals) employ another person (agent) to provide a service and then delegate the authority in making decisions to the agent (Luayyi, 2010). The delegation of authority is carried out by entering into a contract between the principal and the agent. Proper contract planning to align the interests of managers and owners in the event of a conflict of interest is at the heart of agency theory. However, creating the right contract is a difficult thing to realize. Therefore, investors are required to give the managers a residual control right, i.e. the right to make decisions in certain conditions that have not previously been seen in the contract (Nuswandari, 2009).

According to Sari (2016), signaling theory explains why companies have the motivation to provide financial statement information to external parties. This motivation arises because of asymmetric information between the company (management) and external parties, where management knows the company's internal information which is relatively more abundant and faster than outside parties such as investors and creditors.

\section{Tax Avoidance}

The characteristics of a company can affect tax avoidance. Tax avoidance itself can be categorized as either a legal activity or an illegal activity depends on whether the transaction is carried out solely for tax avoidance and does not have a good business. Maharani and Suardana (2014:525-539) define tax avoidance as a way to legally avoid taxes that does not violate tax rules. Meanwhile, according to Annisa (2015) tax avoidance is the arrangement of transactions carried out by companies to obtain tax advantages, benefits, or reductions in the manner intended by tax law without violating the applicable tax rules. At this time the practice of tax avoidance is growing and supported by the development of information technology. 
Moreover, the increasingly open economy of a country will provide opportunities for companies to develop their business both locally and to overseas in the midst of increasingly fierce business competition. Entrepreneurs will try to get as much profit as possible and also to reach tax efficiency.

\section{Profitability}

According to Fahmi (2014), profitability is the company's ability to earn profits in relation to sales, total assets and own capital. While Kasmir (2014) stated that companies with high returns on investment have relatively small debt because high returns allow companies to finance most of their internal funding. In other words, companies with large retained earnings will use retained earnings first before deciding to use debt. Return on Assets (ROA) is a ratio used to measure the company's ability to generate profits from investment activities. This ratio is used to measure management's ability to obtain overall profits. The greater the Return on Assets (ROA), the greater the level of profit achieved by the company and the better the company's position in terms of assets use.

\section{Leverage}

According to Kasmir (2014), in Wastam Wahyu.H (2017), Leverage is a ratio used to measure the extent to which a company's assets are financed by debt, i.e. how much debt is borne by the company compared to its assets. In other words, this ratio is used to measure the company's ability to pay all of its obligations, both short-term and long-term (total debt/total assets). Debt to Equity Ratio (DER) is a comparison between the total debt generated by the total equity obtained by the company as a source of funding. Companies that use debt in the composition of financing will incur interest expenses that must be paid. Interest expense is a deductible expense against taxable income, causing the company's taxable profit to be reduced and, in the end, it will reduce the amount of tax that must be paid by the company. This means that the higher the Debt to Equity Ratio, the greater the total debt to the company's total equity. Companies with too many obligations will find it difficult to get additional funds from outside. This will have an impact on companies that are most likely to make minimum tax payments.

\section{Company size}

The size of the company will affect the capital structure based on the fact that a larger company has a high sales growth rate so that the company will be more daring to issue new shares and the tendency to use the loan amount is also getting bigger. Small-scale companies are more flexible in dealing with uncertainty, because small companies react more quickly to sudden changes. Thus, large companies would have a greater debt level compared to small companies, and a larger amount of debt would also result in a smaller tax burden, thus the size of the company affects tax avoidance.

\section{The effect of Profitability on Tax Avoidance}

Based on the explanation of the theory above, Return On Assets is related to the Signaling theory. Signaling theory states that high company profitability would give a signal that the company has a good performance. With high profits, the company will try to manage their taxes to a minimum value, so that the company's profit or net profit looks high in order to give a signal for investors that the company's performance is good. Based on the results of previous research conducted by Nur Laily (2017), Ulfa Jasmine (2017), Dianing Ratna Wijayani (2017), Komang Subagiastra, I Putu Edi Arizona, and I Nyoman Kusuma Adyana Mahaputra (2016), profitability using ROA has a positive effect on Tax Avoidance. From the description described above, the hypothesis can be concluded as follows:

H1: Profitability has an effect on Tax Avoidance 


\section{The effect of Leverage on Tax Avoidance}

According to Yoanis Carrica Wijayanti and Ni Ketut Lely A. Merkusiwati (2017), Leverage has a positive effect on Tax Avoidance. Leverage (DER) is financial funding by companies originating from the use of debt which can provide benefits as a reduction in the tax expense because the use of debt can cause interest expenses which can reduce the company's taxable income. The funding decision policy set by the company can be described through the company's leverage ratio. However, the research of Gusti Ayu Widya Lestari, I.G.A.M Asri Dwija Putri (2017) and Ni Luh Putu Puspita Dewi and Naniek Noviari (2017) shows that Leverage has a negative effect on Tax Avoidance. High debt causes a low CETR so that it shows high tax avoidance. From the description described above, the hypothesis can be concluded as follows:

H2: Leverage has an effect on Tax Avoidance.

\section{The effect of Company Size on Tax Avoidance}

The agency theory states that the larger the company is, the greater the agency costs that arise. To reduce agency costs, companies will tend to disclose more extensive information. Based on the results of previous research conducted by Khoirunnisa Alviyani (2016), Nur Laily (2017), Ulfa Jasmine (2017), Ngadiman and Christiany Puspitasari (2014), Company Size has an effect on Tax Avoidance. The size of the company is divided into three categories: large firms, medium firms, and small firms. The size of the company will affect the capital structure based on the fact that a larger company has a higher sales growth rate so that the company will be more daring to issue new shares and to take a higher amount of loan. From the description described above, the hypothesis can be concluded as follows:

$\mathbf{H}_{3}$ : Company size has an effect on Tax Avoidance.

\section{METHODOLOGY}

This research could be categorized as quantitative and causal research. Quantitative Research is a systematic scientific study of the parts, phenomena, and the causality of their variables' relationships. The purpose of quantitative research is to develop and use mathematical models. Causal research is used to prove the relationship between cause and effect of several variables. Causal research usually uses the experimental method, which is by controlling the independent variable that will affect the dependent variable in the planned situation. In this case, it is necessary to test the relationship between the two or more variables. The purpose of this study is to examine the effect of the independent variables, which are Profitability, Leverage and Firm Size on the dependent variable, which is Tax Avoidance. The population in this study are the Automotive sector Manufacturing Companies in Indonesia which are listed on the Indonesia Stock Exchange (IDX) in the period of 2012-2019.

\section{Variable Operationalization}

According to Sugiyono (2017:38) independent variables are variables that affect or are the cause of changes and emergence of the dependent variable. The independent variables in this study are as follows: Profitability, proxied by Return On Assets, i.e. the comparison between net income and total assets at the end of the period, could be used as an indicator of the company's ability to generate profits (Kurniasih \& Sari, 2013). According to Kasmir (2016:201) Return on Assets is used to show the company's ability to 
generate profits by using its total assets. Return on Assets can be calculated using the ratio of net income after tax to all assets owned, which can be mathematically formulated as follows:

$$
\text { Return On Asset }(\mathrm{ROA})=\frac{\text { Net Income }}{\text { Total Asset }}
$$

According to Kurniasih and Sari (2013: 63) leverage is a ratio that measures the ability of both long-term and short-term debt to finance company assets and is measured using the debt to equity ratio. Debt to Equity Ratio (DER) is a ratio that compares the total debt generated with the total equity obtained by the company as a source of funding. According to Kasmir (2016:157), Debt to Equity Ratio is a ratio used to assess debt and equity. This ratio describes the extent to which the capital owned can cover debts to outside parties. The smaller this ratio, the better for the company. This ratio can be calculated using the following formula:

$$
\text { Debt to Equity Ratio }=\frac{\text { Total Debt }}{\text { Total Equity }}
$$

Machfoedz (in Suwito and Herawati, 2005: 138) states that company size is a scale that can classify companies into large and small companies based on various aspects, such as: total assets of the company, stock market value, average sales level, and number of sales. The size of the company (Size) that is proxied by $\operatorname{Ln}$ (Total Assets) is considered better because this company size has a more stable level than other proxies and tends to be continuous between one period and the next (Prakosa, 2014). Company size is measured using the natural logarithm of total assets (Prakosa, 2014). The formula for calculating company size is as follows:

$$
\text { Company Size }=\operatorname{Ln}(\text { Total Asset })
$$

According to Sugiyono (2017:39), dependent variable is a variable that is influenced or is the result of the existence of independent variable. In this study, the dependent variable is Tax Avoidance. Tax avoidance is an attempt to reduce, or even eliminate, the tax debt that must be paid by the company without violating applicable laws. Measurement of Tax Avoidance in this study uses the measurement of the Cash Effective Tax Rate (CETR). The formula used to calculate tax avoidance is as follows:

$$
\text { CETR }=\frac{\text { Tax payable by the company }}{\text { Company income before tax }}
$$

\section{RESULTS AND DISCUSSIONS}

\section{Descriptive Statistical Analysis}

Descriptive statistical analysis aims to explain and provide a statistical overview of all the variables in the sample data, which includes: mean, median, maximum and minimum values, as well as sizes, which can be seen in the following table.

\section{Table 1}

Descriptive Statistical Analysis Test Table

\begin{tabular}{|l|c|c|c|c|}
\hline & CETR & ROA & DER & SIZE \\
\hline Mean & 0.552750 & 0.128594 & 0.518875 & 13063.81 \\
\hline Median & 0.245000 & 0.097000 & 0.416500 & 12720.00 \\
\hline Maximum & 9.893000 & 0.309000 & 1.029000 & 14546.00 \\
\hline Minimum & 0.052000 & 0.002000 & 0.102000 & 12159.00 \\
\hline Std. Dev. & 1.706544 & 0.094215 & 0.290434 & 862.0820 \\
\hline
\end{tabular}


The dependent variable Tax Avoidance as measured by the CETR proxy has the highest value of 9.893000 owned by PT Indospring Tbk in 2015, while the lowest tax avoidance is 0.052000 which is also owned by PT. Indospring Tbk in 2019. The average value for the CETR variable is 0.552750 and the standard deviation value for the ETR variable is 1.706544. The independent variable profitability (ROA) has the highest value of 0.309000 owned by PT Selamat Sempurna Tbk in 2014 , and the lowest value of 0.002000 is owned by PT Indospring Tbk in 2015. The average value of the profitability variable is 0.128594 and the standard deviation value of profitability is 0.094215 . The independent variable leverage (DER) has the highest value of 1.029000 owned by PT Astra Internasional Tbk in 2012, and the lowest leverage of 0.102000 owned by PT Indospring Tbk in 2019. The average value of the leverage variable is 0.518875 and the standard deviation value of the leverage variable is 0.290434 . The independent variable company size (SIZE) has the highest value of 14546.00 owned by PT Astra International Tbk in 2019, and the lowest company size value of 12159.00 owned by PT Selamat Sempurna Tbk in 2012. The average value of the company size is 13063.81 and the standard deviation value of the company size is 862.0820.

Table 2.

Chow Test

Redundant Fixed Effects Tests

Equation: FE

Test cross-section fixed effects

\begin{tabular}{lrrr}
\hline \hline Effects Test & Statistic & d.f. & Prob. \\
\hline \hline Cross-section F & 5.340494 & $(3,25)$ & 0.0056 \\
Cross-section Chi-square & 15.847042 & 3 & 0.0012 \\
\hline \hline
\end{tabular}

Source: Data processed in 2020

Since Prob. Cross-section F $=0.0056<0.05$, hence the better model is Fixed effect. Therefore, in this study, the model used is Fixed effect.

Table 3

Hausman Test

Correlated Random Effects - Hausman Test

Equation: RE

Test cross-section random effects

\begin{tabular}{llrr}
\hline \hline Test Summary & \multicolumn{1}{c}{ Chi-Sq. } & \\
Statistic & Chi-Sq. d.f. & Prob. \\
\hline \hline Cross-section random & 16.021482 & 3 & 0.0011 \\
\hline \hline
\end{tabular}

Source: Data processed in 2020

Prob. Cross-section Random $=0.0011<0.05$. Since Prob. Cross-section Random $<0.05$, hence the better model is Fixed effect. Therefore, in this study, the model used is Fixed effect. 
Table 4

Hausman Test

Correlated Random Effects - Hausman Test

\begin{tabular}{lrrr}
\hline \hline Test Summary & $\begin{array}{c}\text { Chi-Sq. } \\
\text { Statistic }\end{array}$ & Chi-Sq. d.f. & Prob. \\
\hline \hline Cross-section random & 16.021482 & 3 & 0.0011 \\
\hline \hline
\end{tabular}

Prob. Cross-section Random $=0.0011<0.05$. Since Prob. Cross-section Random $<0.05$, hence the better model is Fixed effect. Therefore, in this study, the model used is Fixed effect.

Table 4.

Normality Test

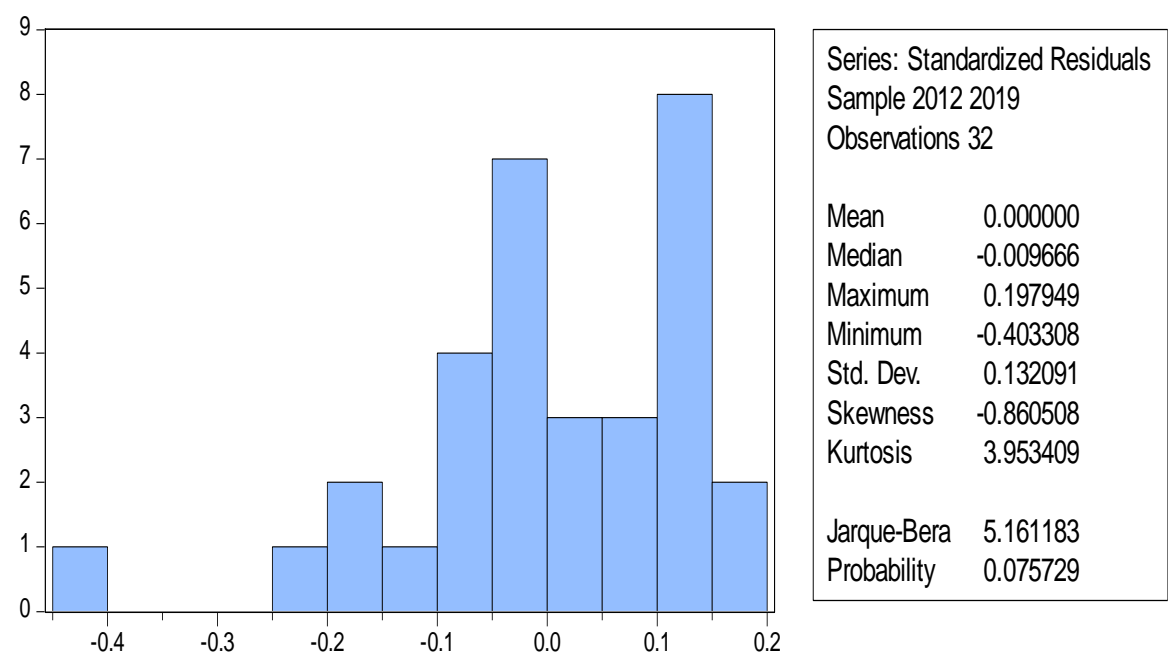

Source: Data processed in 2020

The results of the non-parameter analysis of Jarque-Bera (JB) showed that the data is normally distributed because the probability of all variables is $5.161183>0.05$, therefore $\mathrm{H} 0$ is accepted, which means that the residual data and variables are normally distributed.

Table 5.

Multicollinearity Test

\begin{tabular}{|c|c|c|c|c|}
\hline & CETR & ROA & DER & SIZE \\
\hline CETR & 1.000000 & -0.663448 & 0.114680 & -0.041434 \\
\hline$R O A$ & -0.663448 & 1.000000 & 0.294415 & -0.039354 \\
\hline$D E R$ & 0.114680 & 0.294415 & 1.000000 & 0.687852 \\
\hline SIZE & -0.041434 & -0.039354 & 0.687852 & 1.000000 \\
\hline
\end{tabular}

Source: Data processed in 2020

In table 5 above, it can be seen that the results of the value of the correlation coefficient between the independent variables in this study is within the range of numbers below 0.80 , hence it can be concluded that the data used in this study is free from multicollinearity problems. 
Table 6.

Heteroscedasticity Test

Dependent Variable: RESASB

Method: Panel Least Squares

Date: 06/04/20 Time: 15:36

Sample: 20122019

Periods included: 8

Cross-sections included: 4

Total panel (balanced) observations: 32

\begin{tabular}{crllr}
\hline \hline \multicolumn{1}{c}{ Variable } & Coefficient & Std. Error & t-Statistic & Prob. \\
\hline \hline C & 1.626663 & 1.122396 & 1.449277 & 0.1584 \\
X1 & 0.008387 & 0.048020 & 0.174662 & 0.8626 \\
X2 & -0.061808 & 0.106503 & -0.580342 & 0.5663 \\
X3 & -0.001359 & 0.000996 & -1.365080 & 0.1831 \\
\hline \hline R-squared & 0.205685 & Mean dependent var & 0.124219 \\
Adjusted R-squared & 0.120580 & S.D. dependent var & 0.112701 \\
S.E. of regression & 0.105688 & Akaike info criterion & -1.540177 \\
Sum squared resid & 0.312760 & Schwarz criterion & -1.356960 \\
Log likelihood & 28.64282 & Hannan-Quinn criter. & -1.479445 \\
F-statistic & 2.416838 & Durbin-Watson stat & 1.381090 \\
Prob(F-statistic) & 0.087366 & & & \\
\hline \hline
\end{tabular}

Source: Data processed in 2020

From Table 6 above, it can be seen that the heteroscedasticity test showed that the probability of each independent variable $(0.8626 ; 0.5663 ; 0.1831)$ is greater than 0.05 . Hence, it can be concluded that the data in this research variables does not have heteroscedasticity in the model.

\section{Hypothesis Test}

Based on Table 6 the coefficient of determination test results obtained the adjusted $\mathrm{R}^{2}$ value of 0.808302 . This adjusted $\mathrm{R}^{2}$ value indicates that all independent variables consisting of Return On Assets, Debt to Equity Ratio and Company Size (Size) can explain $80.83 \%$ of the variation of the dependent variable, which is Tax Avoidance, while the rest can be explained by other variables that are not included in the research.

The results of the partial test (t-test) can be seen in Table 4.9. Based on Table 4.9, conclusions can be drawn regarding the effect of each independent variable, namely Return On Assets, Debt to Equity Ratio and Natural Logarithm of Total Assets on the dependent variable, namely Tax Avoidance. Based on table 4.9, it can be seen that the Return On Asset (ROA) variable has a regression coefficient value of -0.786934 and a t-count value of -7.619628 with a significance value of 0.0000 which is smaller than $5 \%$. These results indicate that Return On Assets (ROA) has a significant negative effect. Therefore, the first hypothesis (H1) can be concluded that the Profitability (ROA) variable has a negative effect on Tax Avoidance (CETR) in Automotive Companies listed on the Indonesia Stock Exchange. Based on Table 8, it can be seen that the Leverage (DER) variable has a regression coefficient value of 1.246662 and a t-count value of 4.280780 with a significance value of 0.0002 which is smaller than $5 \%$. 


\section{Table 7}

\section{Regression Analysis}

Dependent Variable: $Y$

Method: Panel Least Squares

Date: 06/04/20 Time: 15:33

Sample: 20122019

Periods included: 8

Cross-sections included: 4

Total panel (balanced) observations: 32

\begin{tabular}{crlrr}
\hline \hline \multicolumn{1}{c}{ Variable } & Coefficient & Std. Error & t-Statistic & Prob. \\
\hline \hline C & -28.00216 & 15.64782 & -1.789525 & 0.0857 \\
X1 & -0.786934 & 0.103277 & -7.619628 & 0.0000 \\
X2 & 1.246662 & 0.291223 & 4.280780 & 0.0002 \\
& 0.024262 & 0.014152 & 1.714407 & 0.0988 \\
\hline \hline \multicolumn{5}{c}{ Effects Specification } \\
\hline Cross-section fixed (dummy variables) & & \\
\hline \hline & & & \\
R-squared & 0.845405 & Mean dependent var & -0.578594 \\
Adjusted R-squared & 0.808302 & S.D. dependent var & 0.335950 \\
S.E. of regression & 0.147090 & Akaike info criterion & -0.804903 \\
Sum squared resid & 0.540887 & Schwarz criterion & -0.484273 \\
Log likelihood & 19.87845 & Hannan-Quinn criter. & -0.698623 \\
F-statistic & 22.78551 & Durbin-Watson stat & 1.234017 \\
Prob(F-statistic) & 0.000000 & & \\
\hline \hline
\end{tabular}

Source: Data processed in 2020

These results indicate that the Debt to Equity Ratio has no effect. Therefore, the second hypothesis (H2) can be concluded that the variable Leverage (DER) has a positive effect on Tax Avoidance (CETR) in Automotive Companies listed on the Indonesia Stock Exchange. Based on table 8, it can be seen that the variable Company Size (Size) has a regression coefficient value of 0.024262 and a t-count value of 1.714407 with a significance value of 0.0988 which is greater than $5 \%$. These results indicate that the size of the company (Size) does not have a significant effect. Therefore, the third hypothesis (H3) can be concluded that the variable Company Size (Size) has no effect on Tax Avoidance (CETR) in Automotive Companies listed on the Indonesia Stock Exchange. Simultaneous Test (Test F) was done to determine whether Profitability (ROA) (X1), Leverage (DER) (X2) and Company Size (SIZE) (X3) have a simultaneous effect on Tax Avoidance (CETR) (Y). Based on the test results in table 4.10 (the results of the Regression Model fixed effect), it can be seen that the calculated $\mathrm{F}$ value is 22.78551 with a significance value of 0.000000 which is smaller than 5\%. Therefore, it can be concluded that Profitability (ROA) (X1), Leverage (DER) ) (X2), Firm Size (SIZE) (X3) has a simultaneous effect on Tax Avoidance (CETR) (Y).

\section{Discussions}

\section{The effect of Profitability on Tax Avoidance}

Based on the regression analysis results presented in Table 4.9 particularly the Profitability variable as proxied by the Return On Assets (ROA) ratio, it was proven that ROA has a negative effect on CETR. This study contradicts the research conducted by Deddy Dyas Cahyono et al. 
(2015). However, this research is in line with research by Ulfa Jasmina (2017), Ngadiman and Puspitasari (2014), Dianing Ratna Wijayanti (2017), Komang Subagiastra et al (2016), Naniek Noviasari and Dewi (2017), Ririh Astrisna Ganiswari (2019) and Melisa Fadila (2017) which shows that profitability has a significant effect on Tax Avoidance.

These results indicate that companies with a higher level of profit has a lower value of CETR, which means that the lower the CETR level, the higher the level of tax avoidance. Return on Assets reflects a company's performance in generating net income. The higher the profit generated, the more likely the company is to avoid tax, because the company wants to display large profits by minimizing the tax expense. By minimizing the tax expense, the company will provide maximum results for the company's profits. This was done by the company to give a signal to investors that the company's performance is good.

\section{The effect of Leverage on Tax Avoidance}

Based on the regression analysis results presented in Table 4.9 particularly the Leverage variable as proxied by the Debt to Equity Ratio (DER), it was proven that DER has a positive effect on CETR. This research contradicts the research of Khoirunnisa Alviyani (2016), Deddy Dyas Cahyono et al (2016), Ngadiman \& Puspitasari (2014) and Melisa Fadila (2017). However, this research is in line with the research of Yoanis Carrica Wijayanti and Ni Ketut Lely A. Merkusiwati (2017) which shows that Leverage has a positive effect on Tax Avoidance.

These results indicate that companies with a higher level of leverage has a lower level of CETR. This means that the lower the level of CETR, the higher the level of tax avoidance. This means that the higher the leverage, the higher the Tax Avoidance. Leverage has an effect on Tax Avoidance because debt that results in the emergence of interest expense can be deductible from taxable profit, while dividends from retained earnings cannot be deductible from profit. Interest expense that can be used as a deduction from taxable profit is interest expense that arises as a result of loans to third parties or creditors who have no relationship with the company (Marfu'ah, 2015).

\section{The effect of Company Size on Tax Avoidance}

Based on the regression analysis results presented in Table 4.9 particularly the Company Size variable as proxied by the natural logarithm of Total Assets, it was proven that Company Size has a positive effect on CETR. This research contradicts with Deddy Dyas, Rita Andini, and Kharis Raharjo (2016) and Ririh Atrisna Ganiswari (2019). On the other hand, this research is in line with Alviyani (2016), Nur Laily (2017), Ulfa Jasmine (2017), Ngadiman \& Puspitasari (2014), and Melisa Fadila (2017) showing that profitability has a positive effect on Tax Avoidance. These results indicate that companies with a higher level of company size has a lower level of CETR. This means that the lower the CETR level, the level of tax avoidance will increase. Hence, the higher the size of a company, the higher the tax evasion by the company. The effect of this variable is because paying taxes is the company's obligation. Large companies or small companies will always be chased by the tax authorities if they violate tax provisions.

\section{CONCLUSIONS AND SUGGESTIONS}

Based on the results of data processing and hypothesis testing on all variables that have been carried out, the conclusions of this study are as follows: Profitability (ROA) has a negative effect on Tax Avoidance. This is based on hypothesis testing or significant test ( $t$ test) with $t$ value = - 
7.619628 and probability (sig) $=0.0000<(\mathrm{sig}) 0.05$. Profitability (ROA) can increase the level of tax avoidance. The higher the profit generated, the more likely the company is to avoid tax, because the company wants to display large profits, namely by minimizing the tax expense.

Leverage (DER) has a positive effect on Tax Avoidance. This is based on hypothesis testing or significant test ( $\mathrm{t}$ test) with $\mathrm{t}$ value $=4.280780$ and probability value (sig) $=0.0002<$ (sig) 0.05 . Leverage (DER) can increase the level of tax avoidance. The higher the leverage, the higher the Tax Avoidance. Leverage has an effect on Tax Avoidance because debt that results in the emergence of interest expense can be a deduction from taxable profit, while dividends from retained earnings cannot be deductible from profit.

Company Size (SIZE) has no effect on Tax Avoidance. This is based on hypothesis testing or significant test $(\mathrm{t}$ test) with $\mathrm{t}$ value $=1.714407$ and probability value $(\mathrm{sig})=0.0988>(\mathrm{sig}) 0.05$. Company size can increase the level of tax evasion. The higher the size of the company, the higher the tax avoidance done by the company, because paying taxes is the company's obligation. Large companies or small companies will always be chased by the tax authorities if they violate tax provisions.

\section{Suggestions}

Adding other variables such as audit committee variables and institutional ownership, or adding mediating or intervening variables and control variables so that further researchers can find out whether or not these variables affect tax avoidance. Using other companies other than automotive companies, for example companies engaged in services, manufacturing, banking, telecommunications and so on, so that they are not limited to the automotive sector. So that it can be used as material to increase knowledge and insight about Tax Avoidance, so that company management can design a mechanism for implementing the company's sustainability properly and correctly. It is hoped that the government will further clarify the tax avoidance law in order to narrow down the tax avoidance actions by the taxpayers and make special requirements for companies that have debt with a certain ratio including interest, so that companies do not take advantage of debt interest as a tax deduction. Investors must really pay attention to whether the company practices tax avoidance legally or illegally by employing experts in the field of taxation, so as not to cause negative impacts in the future

\section{REFERENCES}

http://www.idx.co.id

Alfiyani, K. (2016). Pengaruh Corporate Governance, Karakter Eksekutif, Ukuran Perusahaan dan Leverage terhadap Penghindaran Pajak (studi pada perusahaan pertanian dan pertambangan yang terdaftar di BEI tahun 2011-2014). Fekon Vol. 3 No. 1 (Februari) 2016.

Cahyono, A. \&. (2016). Pengaruh Komite Audit, Kepemilikan Institusional, Dewan Komisaris, Ukuran Perusahaan, Leverage dan Profitabilitas terhadap Tindakan Penghindaran Pajak pada perusahaan perbankan yang listing BEI periode tahun 2011-2013. Journal of Accounting, Volume. 2 No. 2 Maret 2016.

Fadila, M. (2017). Pengaruh ROA, Leverage, Ukuran Perusahaan Kompensasi Rugi Fiskal, Kepemilikan Institusional dan Koneksi politik terhadap Penghindaran Pajak. JOM Fekon, Vol. 4 no. 1 (Februari) 2017.

Hidayat, W. W. (2018). Pengaruh Profitabilitas, Leverage dan Pertumbuhan Penjualan terhadap Penghindaran Pajak : studi kasus Perusahaan manufaktur di Indonesia. Jurnal Riset Manajemen dan Bisnis (JRMB) vol 3, no. 1 februari 2018, 19-26. 
Jasmine, U. (2017). Pengaruh Leverage, Kepemilikan Institusional, Ukuran Perusahaan dan Profitabilitas terhadap Penghindaran Pajak (studi pada perusahaan manufaktur yang terdaftar di BEI tahun 2012 - 2014). JOM Fekon Vol.4 No.1 (Februari) 2017.

Laily, N. (2017). Pengaruh Kepemilikan Institusional, Proporsi Dewan Komisaris, Leverage, Ukuran Perusahaan dan Return on Asset terhadap Penghindaran Pajak pada Perusahaan Manufaktur. STIE Perbanas Surabaya.

Merkusiwati, W. \&. (2017). Pengaruh Proporsi Komisaris Independen, Kepemilikan Institusional, Leverage dan Ukuran Perusahaan pada Penghindaran Pajak. ISSN: 2302-8556 E-Jurnal Akuntansi Univ Udayana Vol.20.1. July 2017, 699-728.

Noviari, D. \&. (2017). Pengaruh Ukuran Perusahaan, Leverage, Profitabilitas dan Corporate Social Responcibility terhadap Penghindaran Pajak. E-jurnal Akuntansi Univ. Udayana Vol 21.1. Oktober (2017), 830-859.

Puspitasari, N. \&. (2014). Pengaruh Leverage, Kepemilikan Institusional dan Ukuran perusahaan terhadap Penghindaran Pajak pada perusahaan sektor manufaktur yang terdaftar di BEI 2010-2012. Jurnal Akuntansi/Volume XVIII, no. 3, September 2014, 408-421.

Putri, L. \&. (2017). Pengaruh Corporate Governance, Koneksi Politik dan Leverage terhadap Penghindaran Pajak. E-Jurnal Akuntansi Universitas Udayana vol.18.3 Maret (2017), 20282054.

Subagiastra, A. \&. (2016). Pengaruh profitabilitas, Kepemilikan Keluarga, dan Good Corporate Governance terhadap Penghindaran Pajak (studi pada peusahaan manufaktur di BEI Indonesia). Jurnal Ilmiah Akuntansi Vol. 1, No. 2, Desember 2016, 167-193.

Wijayani, D. R. (2017). Pengaruh Pofitabilitas, Kepeilikan Keluarga, Corporate Governance dan Kepemilikan Institusional terhadap Penghindaran Pajak di Indonesia (studi empiris Perusahaan manufaktur yang listed di BEI 2012-2014). JDEB Vol. 14 No. 02 Maret 2017. 


\section{DECLARATIONS}

\section{Funding}

The authors received no financial support for the research and publication of this article.

Conflicts of interest/ Competing interests:

The authors have no conflicts of interest to declare that are relevant to the content of this article.

\section{Data, Materials and/or Code Availability:}

Data sharing is not applicable to this article as no new data were created or analyzed in this study.

\section{How to cite this Article}

Siregar, A.0, (2021). The Effect of Profitability, Leverage and Company Size on Tax Avoidance in the Automotive Sector Manufacturing Companies. AKURASI: Jurnal Riset Akuntansi Dan Keuangan, 3(2), 103 - 116. 